\title{
The difistory of the
}

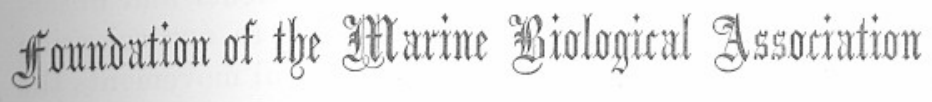 of the eatnited acimgdont.}

In the 'Times,' March 31st, 1884, appeared the following article :

Biological station, some may be inclined to think, is simply Aquarium "writ large." The two certainly do coincide to some extent; a biological station as a rule implies an aquarium, but it includes a great deal more. In the early days of public aquaria, some twenty-five years ago, and down indeed to more recent times, attempts were made to utilise these institutions for scientific purposes, and biologists hoped that great results would follow from their establishment. It was in 1860 that the late $\mathrm{Mr}$. Lloyd designed an aquarium for Paris, and two years later a similar one for Hamburg. Others soon followed, both in this country and on the Continent, nearly all of them constructed on the method devised by Mr. Lloyd, and several of them under his direct superintendence. Probably the earliest on a large scale in this country was the well-known establishment at the Crystal Palace, to the management of which Mr. Lloyd succeeded on the death of Mr. J. K. Lord. Others soon followed at Brighton, Manchester, Southport, Westminster, Yarmouth, Edinburgh, Rothesay, and many other towns in this country; not to mention Vienna, Dresden, Frankfort, New York, San Francisco, VOI. I, NO. I. 
most of which Mr. Lloyd had something to do. At the Crystal Palace, Brighton, Birmingham, and elsewhere, efforts were made to make these aquaria serve the purposes of scientific research, and at the same time to keep them open to the public as places of entertainment and some little instruction. In some of them naturalists' rooms or laboratories were established, and experiments and observations attempted with a view to adding to our scientific knowledge of the creatures whose graceful movements the public never tire of admiring. But the great essential of all such institutions was and is that they should pay. They were regarded by shareholders and managers as simply forming part of their big show, not to be compared in attractiveness to nigger minstrels, Lulu, or a Chinese juggler, but still useful as a bait to catch certain classes of the public. Naturally the views and aims of the management and of the presiding naturalist clashed, and the latter had either to adapt himself to the leading purpose of the establishment or to resign. At all events, it finally became evident to biologists that science could expect little help from the ordinary aquarium, which was no more than a handmaid to the amusement of the public. To accomplish her noble purposes she must be mistress. We believe the French were the first to recognise this important truth, and to establish a station solely for the purpose of investigating the habits, organisation, and surroundings of the denizens of the ocean. Now they have quite a number of such stations in operation-as, for instance, at Roscoff, Concarneau, Villefranche, and Cette. The Austrian Government maintains a similar station at Trieste, while in America the John Hopkins University has one at Beaufort, and Professor Alexander Agassiz another at Newport. The Dutch have for several years had a travelling laboratory erected during the summer months at different parts of their coasts. But undoubtedly the finest institution of the kind is that founded ten years ago at Naples by a German biologist, Dr. Anton Dohrn, to the work of which we have at various times referred in our columns. The Naples station is indeed an international institution, for although it is subsidized to the extent of $£ 1500$ a year by the German Government, its workers and much of the rest of its income, which in all amounts to about $£ 5000$ a year, come from all parts of the world. The University of Cambridge maintains a table for one of its students, as does also the British Association. America has always one or two investigators working under Dr. Dohrn, while various European countries have their representatives. Not only has the Naples station its tanks and its laboratories, but it maintains steam launches and boats of various kinds, diving apparatus for investigating the sea bottom, dredges and trawlers, sailors and fishermen trained as collectors, and issues regularly a series of handsome 'Transactions,' comparable to the publications of our "Challenger" expedition. The advances made in the special department of biology connected with fishes since the establishment of the Naples' station has been immense, and has had besides important bearings on other departments of the same branch of science. In this country no regular station of the kind has existed until within the last few months, when, under the auspices of the Scottish Meteorological Society, one has been established in an old quarry at Granton on the Firth of Forth, near Edinburgh. Already the naturalists at Granton have done good work in investigating the habits of the economical fishes, and especially the herring, and some of the results of their work were described to the Royal Society last Thursday by Professor Cossar Ewart, of Edinburgh. For several years the British Association has had a committee to superintend the working of a Scottish zoological station; but the station has been peripatetic and temporary, maintained only during the summer months at different parts of the Scottish coast; nevertheless it has done excellent work. British naturalists have been long convinced that both from a scientific and economical point of view it is high time that a permanent station on the model of that of Naples were established at some suitable point on the coast of England. The success of the recent Fisheries Exhibition has encouraged this prevalent feeling, and has led our leading scientific men to 
take definite steps to place England in this respect on a level with other countries. As we have already announced, a meeting will be held to-day in the rooms of the Royal Society to carry out this object. This will be accomplished by founding a society having for its purpose "the establishment and maintenance of a well-equipped Laboratory at a suitable point on the English coast, similar to, if not quite so extensive as, Dr. Dohrn's zoological station at Naples." Among the supporters of the movement are the most influential naturalists in the kingdom. Professor Huxley, P.R.S., will preside, and others who have promised to be present are Professor Flower, Professor Moseley, Sir Lyon Playfair, Sir John Lubbock, Professor Michael Foster, Professor Ray Lankester, Dr. Günther, Dr. W. B. Carpenter, Mr. Gwyn Jeffreys, Dr. P. L. Sclater, and Mr. W. S. Caine, M.P. (one of the Commission on Trawling). With such powerful support it seems to us that the object in view is sure to be accomplished. Both from an economical and scientific standpoint the utility, indeed the necessity, of such an establishment appears obvious. Already the Granton station has done good service to the Scottish fishermen; but even if no ends were to be served by such a station except those of pure science, these in our estimation are so important as to justify the movement which has secured such influential support. The utility in its highest, and even in its lowest, sense of encouraging scientific research may now be taken as recognised in all civilized countries. All the most valuable "practical" discoveries have been made by men who were not seeking for them, but whose sole aim was to satisfy a noble inquisitiveness. Our Government recognises the necessity of encouraging science in its magnificent establishments at Bloomsbury and South Kensington, and in its subsidy of $£ 5000$ a year to the Royal Society for purposes of research; and none but chronic grumblers would grudge another $£ 1000$ a year to the support of the proposed station, which indeed may be regarded as an almost indispensable adjunct to the Natural History Department at South Kensington. The necessity for research in this direction was recognised at the final meeting of the Fisheries Exhibition Commissioners, when they voted $£ 3000$ for the formation of a Royal Fisheries Society. They have still $£ 2000$ in reserve, and as the exhibition was as much scientific as economic it seems only natural that part of this should find its way to help in the construction of a station whose sole purpose would be the investigation of the habits and organisation of the fishes of our British waters. On every side we are told that something must be done for the improvement of our fisheries; science has done so much in recent years to improve every other department of industry that, in our opinion, it is quite worth while asking her to do something for a department which is of growing economical importance. She must, however, be allowed to do it in her own way, and the names of those who are to take part in the meeting of to-day are a sufficient guarantee that any funds with which the future society will be entrusted will not be abused. The movement is one which certainly deserves public support and the countenance of the Government.

It is intended to erect the proposed Laboratory at a point as rich as possible in respect of its marine Fauna, and at the same time in proximity to important fishing grounds. No locality, we are told, has yet been decided, but both Torquay and Weymouth have been suggested as presenting the desired combination. There can be little doubt that Monday's meeting will be the first step to the accomplishment of the great object in view, in the near future.

The meeting was duly held in the afternoon of March 31st, 1884, in the Rooms of the Royal Society, and the report of it, which has been reprinted in the following pages, was largely circulated. 